\title{
MODEL NUMBERED HEAD TOGETHER DAN ROUND ROBIN: STUDI PERBEDAAN HASIL BELAJAR SISWA PADA POKOK BAHASAN SISTEM PERIODIK UNSUR
}

\section{NUMBERED HEAD TOGETHER AND ROUND ROBIN MODELS: STUDY OF DIFFERENCE STUDENT LEARNING OUTCOMES ON THE SUBJECT OF PERIODIC TABLE OF ELEMENTS}

\author{
Jumiati, Muflihah, Nurlaili* \\ Program Studi Sarjana Pendidikan Kimia, Fakultas Keguruan Ilmu Pendidikan, Universitas Mulawarman, \\ Samarinda, Kalimantan Timur, Indonesia \\ *Corresponding Author: nurlailisyamsul@yahoo.com
}

\begin{abstract}
ABSTRAK
Dalam model pembelajaran numbered head together (NHT), siswa saling bekerja sama dan berdiskusi dalam kelompok, kemudian mengemukakan pendapatnya secara individu. Dalam model pembelajaran round robin, siswa bergiliran memberikan kontribusi menjawab pertanyaan dalam suatu kelompok. Penelitian ini bertujuan untuk mengetahui perbedaan hasil belajar antara siswa yang diajar dengan model pembelajaran kooperatif tipe NHT dan siswa yang diajar dengan model pembelajaran kooperatif tipe round robin pada pokok bahasan sistem periodik unsur. Sampel penelitian adalah siswa kelas X-Keperawatan B dan C dengan masing-masing kelas berjumlah 36 siswa. Kedua kelompok sampel dipilih menggunakan teknik purposive sampling. Siswa kelas X-Keperawatan B diajar menggunakan model NHT dan siswa kelas XKeperawatan $\mathrm{C}$ diajar menggunakan model round robin. Hasil belajar siswa diperoleh dengan cara tes yang diberikan pada saat post-test dan ulangan harian. Data hasil penelitian dianalisis menggunakan uji t. Hasil analisis menunjukkan bahwa terdapat perbedaan signifikan $(\alpha=0,05)$ hasil belajar antara siswa yang diajar dengan model NHT dan siswa yang diajar dengan model round robin. Hasil belajar siswa yang diajar menggunakan model pembelajaran round robin lebih baik dibandingkan dengan hasil belajar siswa yang diajar dengan model NHT.
\end{abstract}

Kata kunci: model pembelajaran, kooperatif, NHT

\begin{abstract}
In learning model of numbered head together (NHT), students collaborate and discuss in a group, then express their opinion individually. In learning model of round robin, students contribute to answer question alternately in a group. This research aimed to know difference of learning outcomes between students taught using cooperative learning model type NHT and students taught using cooperative learning model type round robin on the subject of periodical table of elements. Research samples were tenth grade student namely students of XKeperawatan B and C with 36 of total number of student each group. Both of the group samples were selected by using purposive sampling technique. Students of X-Keperawatan B were taught using NHT model and students of $\mathrm{X}$-Keperawatan $\mathrm{C}$ were taught using round robin model. Student learning outcomes were collected by using test at the end of lesson (post-test) and final subject examination. The data were analyzed using t-test. Results showed that there was a significantly $(\alpha=0.05)$ difference of learning outcomes between students who taught using NHT model and students who taught using round robin model. Learning outcomes of
\end{abstract}


students who taught using round robin model was better than that of students who taught using NHT model.

\section{Keywords: learning model, cooperative, NHT}

\section{PENDAHULUAN}

Mata pelajaran kimia merupakan bagian penting dari ilmu pengetahuan alam. Kimia memiliki hubungan dengan ilmu-ilmu lainn, dan memiliki pengaruh dan hubungan luas dengan kehidupan sehari-hari. Ilmu kimia adlah ilmu yang mempelajari struktur, susunan, sifat, dan perubahan materi serta energi yang menyertai perubahan materi tersebut. Konsep dalam llmu kimia umumnya bersifat abstrak, merupakan penyederhanaan, dan berkembang dengan cepat (Kean \& Middlecamp, 1985; Olayele, 2012). Karakteristik tersebut menjadikan ilmu kimia sulit untuk difahami siswa.

Sistem periodik unsur adalah salah satu pokok bahasan dalam ilmu kimia yang dianggap sulit oleh siswa. Siswa dihadapkan dengan berbagai macam unsur dan simbol dalam tabel periodik dan disuguhkan penggolongan unsur-unsur berdasarkan periode dan golongan. Unsur-unsur di dalam sistem periodik unsur sangat banyak dan menyulitkan siswa untuk mengingatnya (Kusumawardhani, dkk., 2018). Sudarmo (2013), membagi materi sistem periodik unsur kelas X SMA menjadi 21 label konsep pada repsesentasi simbolik.

Konsep-konsep kimia bersifat abstrak dan simbolik dapat diatasi dengan penerapan model pembelajaran yang tepat. Model yang tepat adalah model yang dapat mengaktifkan siswa dalam pembelajaran, salah satunya adalah model pembelajaran kooperatif. Pembelajaran dengan model ini mengaktifkan siswa dalam kelompok untuk meningkatkan diri sendiridan teman belajar dalam kelompok (Hidayah, dkk., 2018). Ada berbagai macam jenid model pembelajaran kooperatif termasuk numbered head together (NHT) dan round robin.

Model pembelajaran NHT terdiri dari empat fase (penomoran, mengajukan pertanyaan, berpikir bersama, dan menjawab). Siswa dikelompokkan secara heterogen, setiap kelompok terdiri 3-5 siswa, dan setiap anggota memiliki satu nomor. Ciri khas model ini terletak pada kesempatan guru menunjuk seorang siswa untuk mewakili kelompoknya tanpa memberitahu terlebih dahulu. Sehingga setiap siswa harus siap. Penggunaan model NHT dapat membuat siswa menjadi aktif dalam pembelajaran (Qurniawati, 2013; Yanti, dkk., 2016). Beberapa penelitian telah dilaporkan bahwa penerapan NHT dalam pembelajaran kimia dapat meningkatkan hasil belajar siswa (Melati, 2010; Qurniawati, 2013; Sufiani, 2016).

Model pembelajaran round robin melatih siswa untuk saling berbagi dalam proses pembelajaran. Model ini diawali pengungkapan suatu ide atau pengajuan suatu pertanyaan oleh guru dan siswa diminta menyampaikan pendapat atau menjawab pertanyaan tersebut. Setiap siswa dalam sebuah kelompok secara bergilir menjawab pertanyaan yang diberikan. Model ini mengurangi dominasi siswa tertentu dalam menjawab pertanyaan kelompok, akibatnya siswa yang jarang mengeluarkan pendapatnya akan menjadi aktif (Suci, dkk., 2016). Round robin model telah terbukti berpengaruh pada hasil belajar kimia siswa (Delina, 2014, Suci \& Haryati, 2016).

Kedua model ini memiliki persamaan yaitu membagi kelas dalam kelompok-kelompok kecil dengan siswa yang heterogen. Masing-masing anggota kelompok dituntut untuk menguasai materi dan mampu menyelesaikan soal yang diberikan oleh guru. Perbedaannya yaitu pada model pembelajaran NHT setiap siswa dalam kelompok bertanggung jawab untuk menjawab pertanyaan guru (Nugroho, 2011). Pada model pembelajaran round robin setiap siswa dalam kelompok memiliki tanggung jawab untuk menjawab pertanyaan yang diberikan guru dan mengemukakan jawaban masing-masing kepada anggota kelompoknya kemudian kelompok menentukan jawaban yang paling tepat untuk dipresentasikan (Delina, 2014).

Berdasarkan uraian di atas penelitian ini dilaksanakan untuk mengetahui perbedaan hasil belajar antara siswa yang diajar dengan model pembelajaran NHT dan siswa yang diajar model round robin pada pokok bahasan sistem periodik unsur.

\section{METODE PENELITIAN}


Peneltian ini dilasksanakan di SMK Medika Samarinda. Sampel penelitian adalah 72 siswa yang terbagi ke dalam 2 kelas yaitu kelas X-Keperawaran B dan C. Kedua group tersebut dipilih secara purposive. Siswa kelas X-Keperawatan B diajar dengan model NHT dan siswa kelas X-Keperawatan $\mathrm{C}$ diajar dengan model round robin. Materi yang diajarkan adalah sistem periodik unsur yang disampaikan sebanyak 3 kali pertemuan. Pertemuan pertama mempelajari materi perkembangan dasar pengelompokkan unsur dan sistem periodik modern. Pada pertemuan kedua mempelajari sifat-sifat periodik unsur. Pada pertemuan ketiga merupakan kegiatan ulangan harian. Hasil belajar (HB) siswa diperoleh melalui tes: post-test dan ulangan harian dengan perhitungan menggunakan pesramaan (1).

$$
\mathrm{HB}=30 \% \mathrm{P}_{1}+30 \% \mathrm{P}_{2}+40 \% \mathrm{UH}
$$

Rata-rata hasil belajar siswa kelas NHT dan round robin diuji perbedaannya menggunakan uji t pada taraf signifikansi $5 \%$.

\section{HASIL DAN PEMBAHASAN}

Hasil belajar siswa yang diajar dengan model NHT dan round robin pada pokok bahasan sistem periodik unsur menjukkan terdapat perbedaan (lihat tabel 1). Dari tabel 1 tampak bahwa hasil belajar siswa yang diajar dengan model round robin lebih baik dibanding hasil belajar siswa yang diajar dengan model NHT. Hasil uji t menunjukkan bahwa $-t_{\text {hitung }}<-t_{\text {tabel }}$ yang berarti terdapat perbedaan signifikan $(\alpha=0,05)$ nilai antara kedua kelas tersebut. Hasil belajar siswa kelas round robin lebih baik daripada hasil belajar siswa kelas NHT.

Fenomena tersebut diakbatkan oleh partisipasi siswa yang optimal selama proses belajar mengajar dengan model pembelajaran round robin. Pada tahap pengerjaan LKS, siswa terlebih dahulu menjawab pertanyaan secara individu kemudian mengemukakan pendapatnya secara bergantian. Hal ini memudahkan siswa dalam memahami dan mengingat kembali apa yang telah dipelajari. Berbeda dengan kelas yang menggunakan model pembelajaran NHT, dimana pada tahap pengerjaan LKS siswa langsung secara bersama-sama mendiskusikan permasalahan bersama kelompok kemudian mengemukakan pendapatnya secara individu. Pada model ini kebanyakan siswa hanya mengetahui jawaban-jawaban setiap soal yang ada dan belum tentu memahami dengan baik dan benar cara kerja penyelesaian setiap jawaban tersebut.
Hal ini disebabkan karena hanya siswa yang memiliki kemampuan lebih yang mendominasi dalam

Tabel 1

Hasil belajar siswa yang diajar dengan model NHT dan round robin pada pokok bahasan sistem periodik unsur

\begin{tabular}{|l|c|}
\hline \multicolumn{1}{|c|}{ Keterangan } & Nilai \\
\hline Rata-rata HB kelas NHT & 78,70 \\
\hline Rata-rata HB kelas round robin & 81,11 \\
\hline $\mathrm{t}_{\text {hitung }}$ & $-2,34$ \\
\hline $\mathrm{t}_{\text {tabel }}$ & $-2,00$ \\
\hline
\end{tabular}

menjawab pertanyaan tersebut. Minat dan motivasi siswa pada kelas kelas yang menggunakan model pembelajaran NHT cukup rendah. Rendahnya minat dan motivasi dalam pembelajaran dapat mempengaruhi hasil belajar yang dicapai. Terutama pada tahap diskusi model pembelajaran NHT siswa cenderung berbicara sendiri di dalam kelompoknya sehingga hanya beberapa siswa yang melakukan diskusi dalam kelompoknya.

Selain itu beberapa hal yang juga berpengaruh dalam mengembangkan minat belajar diantaranya adalah langkah-langkah yang digunakan dalam model pembelajaran NHT dan round robin yaitu penomoran, dimana setiap siswa dalam kelompok akan secara bergantian mengemukakan pendapatnya. Pada model pembelajaran round robin adanya penomoran menjamin keterlibatan semua siswa dan upaya yang sangat baik untuk meningkatkan tanggung jawab individual dalam diskusi kelompok. Dengan adanya keterlibatan semua siswa akan berdampak positif terhadap motivasi belajar siswa yang ditunjukkan dengan hasil belajar yang baik. Sedangkan dalam model pembelajaran NHT juga terdapat tahapan diskusi, tetapi seringkali dalam diskusi siswa hanya mengandalkan kemampuan teman yang lainnya. Hal ini menyebabkan siswa menyerahkan penyelesaian pada teman kelompoknya.

\section{SIMPULAN}

Peneitian di SMK Medika Samarinda ini menujukkan bahwa hasil bejar siswa pada pokok bahasan sistem peridoik yang diajar dengan model pembelajaran kooperatif tipe round robin secara signifikan lebih baik dari hasil belajar siswa yang diajar dengan meodel pembelajaran kooperatif tipe NHT. 


\section{UCAPAN TERIMAKASIH}

Terima kasih penulis sampaikan kepada Bapak Ramli S.Pd. selaku guru mata pelajaran kimia di SMK MEDIKA Samarinda kelas $\mathrm{X}$ yang telah memberikan bantuan dan kerja samanya dalam penyelesaian penelitian ini.

\section{DAFTAR PUSTAKA}

Delina, E. 2014. Penerapan model pembelajaran kooperatif round robin dalam meningkatkan hasil belajar siswa pada mata pelajaran kimia di SMAN 1 Tambang. Skripsi. Pekanbaru: Universitas Islam Negeri Sultan Syarif Kasim Riau.

Hidayah, N., Sholahuddin, A., Sadiqin, I.K., Maulida, N. 2018. Crossing puzzle-cooperative learning vs cooperative learning: studi kasus pada pembelajaran kimia. EduChemia (Jurnal Kimia dan Pendidikan), 3(2), 232-242.

Kean, E., Middlecamp, C. 1985. A survival manual for general chemistry (paduan belajar kimia dasar). Jakarta: Gramedia.

Kusumawardhani, R., Suryati, Khery. Y. 2018. Pengembangan media pembelajaran berbasis android untuk penumbuhan literasi sains siswa pada materi sistem periodik unsur. Hydrogen: Jurnal Kependidikan Kimia, 5(2), 48-56.

Melati, H.A. 2010. Meningkatkan aktivitas dan hasil belajar siswa SMAN 1 Sungai Ambawang melalui pembelajaran model advance organizer berlatar numbered heads together (NHT) pada materi kelarutan dan hasil kali kelarutan. Jurnal Visi Ilmu Pendidikan.

Nugroho, E.A. 2011. Perbedaan hasil belajar siswa antara model pembelajaran NHT (numbered head together) dan STAD (student team achievement division) pada konsep laju reaksi. Skripsi. Jakarta: Universitas Islam Negeri Syarif Hidayatullah.

Olayele. 2012. Enhancing teachers "knowledge for using multiple representations in teaching chemistry in nigerian senior secondary schools.' Australia: Edith Cowan Universit

Suci, D.P., Haryati, S. 2016. Penerapan model pembelajaran kooperatif teknik round robin untuk meningkatkan prestasi belajar siswa pada pokok bahasan ikatan kimia di kelas X SMA Negeri 14 Pekanbaru. Jurnal Online Mahasiswa (JOM) Bidang Keguruan dan Ilmu Pendidikan, $3(2)$.

Sudarmo, U. 2013. Kimia Untuk SMA/MA Kelas X. Jakarta: Erlangga.
Sulfiani, R. 2016. Penerapan model pembelajaran kooperatif tipe numbered head together (NHT) untuk meningkatkan hasil belajar kimia siswa kelas XI IPA1 SMA Negeri 3 Watampone (Studi pada materi pokok struktur atom, sistem periodik unsur dan bentuk molekul), Chemica: Jurnal Ilmiah Kimia dan Pendidikan Kimia, 17(1).

Qurniawati, A., Sugiharto, Saputro, A.N.C. 2013. Efektivitas metode pembelajaran kooperatif tipe numbered head together (NHT) dengan media kartu pintar dan kartu soal terhadap prestasi belajar siswa pada materi pokok hidrokarbon kelas X semester genap SMA Negeri 8 surakarta tahun pelajaran 2012/2013. Jurnal Pendidikan Kimia (JPK), 2(3), 166-174.

Yanti, K.D., Parmiti, D.P., Suwatra, I.I.W. 2016. Pengaruh model pembelajaran kooperatif tipe numbered head together (NHT) terhadap hasil belajar IPA. e-Journal PGSD Universitas Pendidikan Ganesha, 4(1), 1-10. 